\title{
Refuge
}

Canada's Journal on Refugees

revue canadienne sur les réfugiés

\section{A "Worthy" Refugee: Cash as a Diagnostic of "Xeno-Racism" and "Bio-Legitimacy"}

\section{Clayton Todd Boeyink}

Volume 35, Number 1, 2019

Racialized Refuge

URI: https://id.erudit.org/iderudit/1060675ar

DOI: https://doi.org/10.7202/1060675ar

See table of contents

Publisher(s)

Centre for Refugee Studies, York University

ISSN

0229-5113 (print)

1920-7336 (digital)

Explore this journal

Cite this article

Boeyink, C. (2019). A "Worthy" Refugee: Cash as a Diagnostic of "Xeno-Racism" and "Bio-Legitimacy". Refuge, 35(1), 61-71. https://doi.org/10.7202/1060675ar
Article abstract

The refugee regime structure follows a "xeno-racist" colonial genealogy. In this context, refugee cash transfers represent a biopolitical diagnostic, indicating where refugees are worthy or have the "bio-legitimacy" to reside. This article offers a brief genealogy of different iterations of cash operations, which include cash for repatriation at the end of the Cold War, cash for urban Iraqi refugees in Jordan following the second Gulf War, and the Tanzania government's recent decision to abruptly shut down a cash project in Nyarugusu refugee camp. Simply stated, where cash is allowed to flow, so too are refugees.
Copyright (c) Refuge: Canada’s Journal on Refugees, 2019

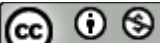

This document is protected by copyright law. Use of the services of Erudit (including reproduction) is subject to its terms and conditions, which can be viewed online.

https://apropos.erudit.org/en/users/policy-on-use/ 


\title{
The "Worthy" Refugee: Cash as a Diagnostic of "Xeno-Racism" and "Bio-Legitimacy"
}

\author{
CLAYTON BOEYINK ${ }^{1}$
}

\section{Abstract}

The refugee regime structure follows a "xeno-racist" colonial genealogy. In this context, refugee cash transfers represent a biopolitical diagnostic, indicating where refugees are worthy or have the "bio-legitimacy" to reside. This article offers a brief genealogy of different iterations of cash operations, which include cash for repatriation at the end of the Cold War, cash for urban Iraqi refugees in Jordan following the second Gulf War, and the Tanzania government's recent decision to abruptly shut down a cash project in Nyarugusu refugee camp. Simply stated, where cash is allowed to flow, so too are refugees.

\section{Résumé}

La structure du régime des réfugiés suit une généalogie coloniale "xéno-raciste». Dans ce contexte, les transferts d'argent aux réfugiés représentent un diagnostic biopolitique indiquant où les réfugiés sont dignes ou ont la «biolégitimité» de résider. Cet article propose une brève généalogie des différentes itérations des opérations de transfert d'argent, dont le rapatriement d'argent à la fin de la Guerre froide; l'aide en espèces pour les réfugiés urbains irakiens en Jordanie suite à la seconde Guerre du Golfe; et la décision récente du gouvernement tanzanien de brusquement mettre fin à un programme de transfert d'argent dans le camp de réfugiés de Nyarugusu. En bref, là où l'argent est autorisé à circuler, les réfugiés le sont également.

\section{Introduction}

Dilippo Grandi, un High Commissioner for Refugees $\checkmark$ (UNHCR), announced in 2017, "Our cash support1 most in the form of multi-purpose grants-reached 2.5 million people in 2016, and for the first time exceeded in-kind assistance." ${ }^{2}$ UNHCR has been a pioneer in institutionalizing humanitarian cash transfers, beginning with repatriation cash projects. ${ }^{3}$ These return operations include one-off or time-limited cash payments for refugees to purchase their needs upon return. In 2008 UNHCR experimented with its first "care and maintenance" cash operations for Iraqi refugees in Amman, Jordan. "Care and maintenance" for refugee situations refer to ongoing and indefinite support for food, shelter, and other needs. Traditionally this has been addressed through in-kind donations, but now cash is increasingly prioritized by humanitarian policymakers because it is generally more cost-efficient than in-kind aid amidst limited humanitarian funding. ${ }^{4}$ I argue refugee cash transfers are not a neutral technical humanitarian intervention, but rather a diagnostic of "xeno-racism" following a

Cette œuvre en libre accès fait l'objet d'une licence Creative Commons Attribution-NonCommercial 4.0 International License, laquelle autorise l'utilisation, la reproduction et la distribution de l’euvre sur tout support à des fins non commerciales, pourvu que l'auteur ou les auteurs originaux soient mentionnés et que la publication originale dans Refuge: revue canadienne sur les réfugiés soit citée. 
colonial genealogy of mobility control where refugees are deemed worthy to reside. ${ }^{5}$ Sivanandan defines xeno-racism as "a racism that is not just directed at those with darker skins, from the former colonial territories, but at the newer categories of the displaced, the dispossessed and the uprooted, who are beating at Western Europe's doors." I extend this analysis to incorporate South-South refugee discriminations. To state it simply, where cash is allowed to flow, so too are refugees. This is not a criticism of the efficacy of cash transfers as an intervention per se. On the contrary, I have heard great praise for cash from refugee recipients in Nyarugusu refugee camp in Tanzania and consider cash transfers as a more efficient and dignified way to deliver aid.

Coordinated primarily by UNHCR, the international refugee regime governs protracted refugee situations through many different modes, including food distribution, education, legal protection, and health care. Cash has been chosen as the locus of this article as a racialized indicator for two primary reasons. First, as the quote from High Commissioner Grandi shows, UNHCR has prioritized cash transfers as an institution. More broadly, the 2016 World Humanitarian Summit in Istanbul, which included the most influential humanitarian donors and organizations, committed to furthering the use of cash in humanitarian settings. ${ }^{7}$ Second, research from the Cash Barometer project identifying humanitarian recipients' attitudes toward cash around the world reveals that the vast majority of recipients favour receiving cash rather than inkind goods. ${ }^{8}$ Agreement from funders, implementers, and recipients denotes that any instances where cash is not used in protracted refugee situations will increasingly be considered an anomaly in need of explanation.

I submit that the fundamental racialized explanation for the refugee cash shutdowns and exclusions in Africa today are the continuities from colonialism of the racially and economically motivated control of African migrations and mobilities. This article interrogates the cash exclusion question empirically by first tracing the historical genealogy of the advent refugee cash transfers for repatriation at the end of the Cold War in the early 1990s. The inclusion of cash for return for Cambodian and Afghan refugees but not for Eritreans demonstrates that the earliest cash transfers clearly reflect donors' geo-strategic priorities of moving refugees for specific ideological benefits to Western powers. Next, we follow the rise of cash for care and maintenance operations beginning with Iraqi refugees in Amman, Jordan, to the present. Today we see African states blocking cash interventions as xeno-racist tools to keep Sub-Sahara African (ssa) refugees out of cities and in the "bio-legitimate" space of camps. In the case of Tanzania, cash has been blocked in cities and camps to signal to refugees they are not worthy to reside anywhere in the country.
The selected cases since the end of the Cold War offer a brief history of refugee cash utilizing a truncated and nonepochal version of Michel Foucault's conceptualization of genealogy. He calls "to identify the accidents, the minute deviations-or conversely, the complete reversals-the errors, the false appraisals, and the faulty calculations that gave birth to those things that continue to exist and have value for us." I examine the "accidents" such as the rise of cash in Jordan, but also the "complete reversals" of cash shutdowns and exclusions in Africa in order to excavate "the various systems of subjection." ${ }^{10}$ The article draws from more than 200 interviews from fieldwork trips in Tanzania between February 2017 and May 2018, primarily with camp residents, the Tanzanian host community surrounding the camp, as well as UNHCR, World Food Programme (WFP), implementing partner NGOS, and Tanzanian government officials. Additional interviews with key individuals involved in cash transfers currently or in the past occurred in UNHCR headquarters in Geneva in April 2017, as well as through Skype. ${ }^{11}$ The majority of refugee households were sampled by research assistants living in the camp through snowball sampling. Before examining the empirical cases of refugees and cash, we will recount the colonial strategies of mobility control in Africa and introduce the concepts of bio-legitimacy ${ }^{12}$ and xeno-racism in the refugee regime today.

\section{Xeno-Racism and Bio-Legitimacy}

There have been attempts to "break the silence" on race in development practice and studies. ${ }^{13}$ White argues, "The silence on race is a determining silence that both masks and marks its centrality to the development project." ${ }^{\prime 4}$ The call to examine race in development was effectively taken up in a special issue of Progress in Development Studies edited by Uma Kothari. ${ }^{15}$ Refugee studies have most notably grappled with racism in this journal, Refuge, in a special issue in 2001. This special issue utilized xeno-racism as a lens to analyze international migration policy in cases around the world. ${ }^{16}$ The present article re-examines xeno-racism as situated by Mark Duffield to demonstrate the racialized nature of cashbased interventions for "non-insured" refugee populations. ${ }^{17}$ Michel Foucault's theorization of discourse and power forms the bedrock of "post-development" critique. ${ }^{18}$ In addition, his writings have inspired many migration and forced migration scholars, although his expansive oeuvre focuses little attention on these issues. ${ }^{19}$ Duffield argues that sustainable development is a bio-political technology with xenoracist and colonial genealogy in order to root "non-insured" populations in the South. ${ }^{20}$ Using Duffield's stance as a point of departure, this article diverges from a bio-political analysis to demonstrate through the genealogical method that refugee cash transfers are a diagnostic of how donors and 
host states judge where refugees have the "bio-legitimacy" to reside.

Foucault introduces bio-power and bio-politics in The History of Sexuality, describing epochal change from sovereign power to bio-power, which is "the ancient right to take life or let live ... replaced by a power to foster life or disallow it to the point of death." ${ }^{21}$ Bio-power can be understood as "an anatomo-politics of the human body," 22 where government disciplines individuals' bodies. Bio-politics is a "series of interventions and regulatory controls: a biopolitics of the population.." ${ }^{23}$ Duffield critiques sustainable development using a bio-political analysis in two important ways that will be borrowed for this article. First, he links the colonial genealogy or "colonial present" of sustainable development today as a bio-political tool to foster self-reliance reminiscent of indirect rule during colonialism. ${ }^{24} \mathrm{I}$ extend this analysis further by pointing to the colonial practices of controlling movements of colonial subjects. Second, Duffield argues that the use of sustainable development by the North is also a xeno-racist bio-political apparatus to keep "non-insured" populations contained in the South. ${ }^{25}$ I contend that African states are rehabilitating these colonial xeno-racist genealogies by disallowing cash for their non-insured refugee neighbours.

Near the end of the nineteenth century, colonial rule shifted from a violent and highly militarized direct form of rule to indirect rule where chiefs were backed as proxies to govern and exploit rural areas of the colonies. Mahmood Mamdani refers to this system as "decentralized despotism."26 Duffield describes the bio-political nature of indirect rule, or Native Administration during the later stages of colonialism: "Within the limits of self-reproduction, the biopolitics of Native Administration aimed to initiate a process of controlled social change through incremental self-management that maintained social cohesion." ${ }^{27} \mathrm{He}$ makes only brief mention of the colonial "concerns over the negative effects of uncontrolled urbanization on social cohesion." ${ }^{28}$ I argue, however, that managing, controlling, and exploiting subjects' movements was a primary concern of the colonial project, the genealogies of which continue today.

Tanzania is a quintessential example of colonial and postcolonial mobility controls and exploitations. First German and later British colonial regimes in Tanganyika ${ }^{29}$ resisted accepting refugees fleeing conscripted labour by the Portuguese colonists in Mozambique by attempting to stop them at the border. They feared these migration flows because they did not want their own subjects to flee their own coercive labour tactics. ${ }^{30}$ Later the British colonists oscillated between recruited neighbouring Burundians to work in labour reserves, and blocking Burundian refugees fleeing conflict in order prevent spreading diseases and interfering with the simplistic colonial understanding of ethnicities and tribes at the borderlands. ${ }^{31}$ Across Africa, onerous taxes in rural areas also impelled movements of people within and across countries in order to pressure them to enter labour markets and cash economies. ${ }^{32}$ Within labour systems in colonial Africa, the city became a contested domain that the colonists wanted to control. This was most pronounced in apartheid South Africa through influx control policies culminating in infamous pass laws and passbooks. The ruling party attempted to balance recruiting enough black Africans to supply labour, while limiting these numbers to ensure racial segregation. ${ }^{33}$ While not going to the same lengths as South Africa, the colonial regime in Tanganyika viewed Africans in Dar es Salaam "suspiciously" and blamed them for urban criminality. They instituted identification documents and rural repatriations, and even spread propaganda about the difficulties of living in the city. ${ }^{34}$

After independence, Tanzania's founding father, President Julius Nyerere, a renowned pan-Africanist, initially enacted progressive immigration and asylum policies. Over time these policies in Tanzania returned to a colonial genealogy of prejudices, restrictions, and exploitation toward refugees and internal urban migrants. ${ }^{35}$ Under Nyerere, refugees were given land to settle in sparsely inhabited peripheries of the country and produced cash crops to benefit the Tanzanian state. ${ }^{36}$ Chaulia elucidates these colonial continuities: "Arguably, development policies of a freely administered nationalistic government were quite different from crude extraction and transfer of wealth under the colonial yoke, but the utilitarian intentions of hosting immigrant labour were more or less consonant with those of the pre-independence era." ${ }^{37}$ Asylum policies have constricted even further today as the result of xeno-racist policies under current Tanzanian President John Magufuli, which will be explored further below.

The other key point from Duffield is his crhtique of sustainable development as a xeno-racist form of bio-political population containment in the South. Xeno-racism is a nationalist project of exclusionary immigration practices. "It is racism in substance but xeno in form-a racism that is meted out to impoverished strangers even if they are white."38 Xeno-racism is aimed at keeping the "other" out of the Global North. Duffield takes this a step further by claiming that wealthy nations (the "insured") demonstrate xeno-racism by engaging in bio-political aid projects to keep unwanted populations in the South (the "non-insured") rooted where they are through sustainable development. ${ }^{39}$ Refugees are the quintessential example of the "non-insured," as they have lost the protection of their citizenship and typically have limited rights under what Rutinwa calls "pseudo-asylum."40 Conceptualizations of insured and non-insured are relative. Xeno-racism is not merely the North containing populations 
in the South but can also be internal South-South containment, as we see for refugees in Africa.

The current global refugee system resonates with Duffield's critique of aid promoting "self-reliance." In 2006 UNHCR promoted a "self-reliance" policy whereby refugees could be less dependent on international donors through their own livelihoods. ${ }^{41}$ However, Duffield does not capture the entire picture of bio-political interventions for non-insured refugees by leaving out from his analysis the humanitarian care and maintenance aspect of international aid. Aid to refugees follows a hybrid logic of care that some refer to as the humanitarian-development nexus. ${ }^{42}$ Most refugee situations provide humanitarian interventions such as ongoing in-kind food aid or cash transfers alongside livelihoods or self-reliance programming. As protracted refugee situations get drawn out, donors reduce support. ${ }^{43}$ With global displacement levels at an all-time high, the main humanitarian donors and organizations have made a major push for cash transfers to make more efficient uses of scarce humanitarian funding in place of in-kind aid. ${ }^{44}$

Like Duffield, most scholars deploying bio-power in their analysis latch onto his phrasing to "foster life." Didier Fassin points out that few scholars address how states' use of biopower will also "disallow [life] to the point of death." ${ }^{45}$ In other words, states create a sense of bio-legitimacy for who is worthy of care. This article does not deploy a bio-political analysis of subjectification, but rather supplements the work of Duffield in exploring the stakes of cash exclusion. Fassin explains this complementarity: "Talking of biolegitimacy rather than biopower is thus to emphasize the construction of the meaning and values of life instead of the exercise of forces and strategies to control it. Considering politics beyond governmentality is similarly to insist on the issues involved in the way human beings are treated and their lives are evaluated more than on the technologies at work in these processes. To use the Foucauldian metaphor, it is moving from the 'rules of the game' to its stakes. These perspectives are not contradictory, but complementary." 46

Returning to Duffield's work, another way of looking at bio-legitimacy is through "worthiness": "The worthiness of developmental-life can be gauged in terms of defending free society. It provides a means of assessing, for example, how useful the life in question is for achieving metropolitan social cohesion, overseas sustainable development, the resolution of internal wars, the reconstruction of fragile states." ${ }^{\text {" } 7}$ We see this "worthiness" clearly in the following examination of refugee repatriation operations at the end of the Cold War. During this era Western powers, primarily the United States and Europe, dominated the agenda of refugee management through border controls and dominance of UNHCR. ${ }^{48}$

\section{The Role of Cash: Cash to Return vs. Cash to Remain}

UNHCR's first use of cash as an intervention was for repatriation operations during the twilight of the Cold War between 1990 and 1993 for Cambodian refugees from Thai camps and Afghan refugees in Pakistan. Concurrently to these return operations in Asia, Eritreans were returning home from Sudan, but received only a fraction of the support and no option for cash interventions. A comparison of these three repatriation operations illustrates the vast discrepancies of donor funding levels and decisions to include or exclude cash programming. These policies by the Western powers to obtain ideological capital in the fight against communism demarcated where donors deemed refugees worthy to reside. These moves echoed colonial manipulations of migrations and people movements for the benefit of the metropoles.

First, the Cambodian refugee situation was the result of decades of conflict since decolonization from the French. The Khmer Rouge, led by Pol Pot, was infamous for its "killing fields" that killed an estimated 1.5 to 3 million people. This regime was toppled by Vietnamese communists supported by the Soviet Union in 1979. A communist coalition was installed known as Cambodian People's Party. The United States supported the counterweight, the Coalition Government of Democratic Kampuchea. The civil war and precipitating events before it created a massive refugee movement to Thailand. The war ended in 1991 and the West desired to repatriate 360,000 refugees before the scheduled 1993 elections in order for them to vote and to secure power to an amenable regime. The expediency of return trumped humanitarian concerns of safe reintegration. ${ }^{49}$ UNHCR decided to offer $\$ 50$ for each adult and $\$ 25$ per child, which would allow for returnees to pay for rent or agricultural materials. This option was chosen by 87 per cent of returnees. ${ }^{50}$

Second, the exodus of refugees from Afghanistan began in 1979 with the Soviet invasion of the country. Most fled to Pakistan or Iran, and each country had nearly three million refugees until the end of the conflict in 1989. Alarmed by the Soviet Union extending its sphere of influence, the United States and United Kingdom mobilized substantial resources to UNHCR and WFP for humanitarian operations supporting Afghan refugees in Pakistan. This support also included substantial military aid channelled through the government of Pakistan. ${ }^{51}$ At the time of the Soviet withdrawal from Afghanistan in 1989, international donor spending, particularly that of the United States, had pared down food aid to Afghan refugees in Pakistan. ${ }^{52}$ Concurrently, and as a result of international donor fatigue, the generosity by the Pakistani state had largely dried up as a result of "asylum fatigue."53 The repatriation operation in Pakistan, called encashment, provided 3,300 Pakistani rupees (US\$100) in exchange 
for refugees' ration cards to be turned in and deregistered. The money was to be used to pay for transportation costs of return. ${ }^{54}$ The cash component of the repatriation project was designed with the explicit goal to get international donors off the financial hook of indefinite funding care and maintenance. ${ }^{55}$

Third, Eritrea formally gained independence in 1993 after a unanimous referendum following an armed struggle against Ethiopia that had been waged since 1961. By the end of the war there were a reported 600,000 refugees residing primarily in eastern Sudan, ${ }^{56}$ and like Cambodian refugees in Thailand, many were eager to return. ${ }^{57}$ Their enthusiasm was met by a tepid response from Western donors because they did not match the ideological and political importance of Cambodia or Afghanistan. ${ }^{58}$ As a result the lack of funding and absence of a cash-based return indicate Eritrean refugees lacked the bio-legitimacy to be assisted home. By 1992 those with the financial means-around 50,000-had spontaneously returned to Eritrea. ${ }^{59}$ Following military victory, the Eritrean government planned for the repatriation of 250,000 refugees between 1992 and 1993. The Eritreans appealed for $\$ 200$ million on the basis of similar repatriation programs such as the Cambodian caseload. UNHCR balked and proposed a mere $\$ 31$ million. $^{60}$ In June 1993 the international community managed to raise only us $\$ 11.7$ million for rehabilitation projects. No cash was offered to returnees, but rather in-kind items such as food and agricultural inputs were provided. ${ }^{61}$ Merely 25,000 of the 250,000 proposed returnees were resettled by 1995. Between 1991 and 1997, 157,345 Eritreans returned spontaneously from Sudan without UNHCR assistance. ${ }^{62}$ Kibreab judges the repatriation project in unequivocal terms: "It is only possible to conclude with the depressing observation that the international community has failed the Eritrean people. It seems completely ludicrous that donors should choose to allocate funds in such a way as to keep thousands of refugees in settlements rather than help them rebuild their homeland. Yet this is what has happened." ${ }^{63}$

Cash for repatriation projects continued into the mid20oos and informed UNHCR's approach to cash for sustaining care and maintenance programs around the world. ${ }^{64}$ UNHCR's first use of cash for care and maintenance programming was inaugurated in 2008 for the Iraqi refugee caseload in Jordan. This program was more stumbled upon by the country staff on the ground than by UNHCR's organizational commitment to cash interventions, according to a UNHCR employee working on the project. ${ }^{65}$ The next section highlights the organizational history of how and why refugee cash interventions rose to prominence globally in ongoing care and maintenance operations, but the same is not afforded to non-Syrian, sSA urban refugees in Africa.

\section{Cash in Amman}

The state of Iraq has had a tumultuous existence since the Saddam Hussein regime invaded Kuwait in 1990, which precipitated a counter-invasion from us-led forces. The second us invasion in 2003 precipitated the fall of Saddam Hussein and descent into sectarian violence. By 2007 over two million Iraqis had been displaced to nearby Middle Eastern countries. ${ }^{66}$ In Jordan the government estimated 450,000500,000 Iraqi refugees resided in the country, although this figure is most likely inflated. ${ }^{67}$ In 2008 UNHCR's first fullscale use of cash in care and maintenance operations was introduced in Jordan. This cash intervention developed as a result of the urban nature of displacement, and the high level of strategic importance of the refugee situation to us and European donors similar to cash for repatriation operations recounted above.

The cash program in Jordan was equally novel in its design and inception. One of the main reasons for the creation of the cash program in Jordan, and why it was so much larger than for the other host countries such as Syria was because Jordan is a middle-income country that did not want the presence of WFP because it did not want to be seen as a "poor country." ${ }^{\text {"WFP }}$ at the time was bound to use vouchers instead of unconditional cash. ${ }^{69}$ This gave flexibility to the UNHCR. One of the UNHCR officers overseeing the cash program said, "We were making it up as we went along." ${ }^{70}$ The Iraqi caseload was primarily urban. More than 80 per cent originated from Baghdad, and 75-90 per cent were displaced to the region's capitals. ${ }^{71}$ Moreover, this refugee population in Jordan has more middle-class, wealthy, and educated people than most refugee contexts. ${ }^{72}$ UNHCR officers "saw in-kind assistance made no sense. It didn't make sense to have people come to UNHCR and get huge bags of grain."73 Recipients could access funds throughout the city through ATMs using iris scans. ${ }^{74}$ These innovations were possible largely because UNHCR was new to the region and could rapidly improvise to fit the situation. ${ }^{75}$

Finally, in order to institute a cash program at the scale of operations in Jordan, funding had to be large and sustained. Amman has a higher cost of living compared to other cities inn which UNHCR has operated. The program in Jordan gave $€ 110$ per person, per month. ${ }^{76}$ While cost efficiency was driven down from 23 per cent for in-kind donations to 2.3 per cent for cash, this was still a costly operation. ${ }^{77}$ This funding was made possible because Iraq-like Cambodia during the end of the Cold War-was of significant global strategic importance to the United States and other Western powers: "Needless to say, the states that have been directly involved in this crisis, by virtue of the troops which they have deployed in Iraq, have a very significant interest in addressing the refugee situation, not least by providing high levels of funding 
and resettlement places." ${ }^{38}$ Funding increased for the Iraqi situation from $\$ 40$ million in 2005 to $\$ 271$ million in $2008 .^{79}$

\section{Urban Refugee Cash in Africa}

UNHCR's handling of the urban caseload informed the organization's broader urban refugee policy ${ }^{80}$ and inspired the expansion of cash. ${ }^{81}$ The Jordan case has not been expanded to urban refugee caseloads in Africa, however. In 2009 UNHCR released an update to its urban refugee policy created in 1997. In the document it states, "In many cities where refugees are unable to establish livelihoods and meet their own needs, UNHCR has provided them with regular sums of money, usually by means of cash payments and sometimes through the distribution of ATM cards." ${ }^{82}$ Why then are there so few urban cash transfer programs despite large populations of refugees in certain African cities? Moreover, for the urban cash programs that exist in Sudan and Egypt, why do they include Syrian rather than African refugees? I conclude that African refugee caseloads, like the Eritrean case above, do not have the geopolitical importance in the current war on terror era. As such, host countries have greater power as xeno-racist gatekeepers to manage the non-insured refugee populations. Moreover, while many post-colonial states deracialized through independence, they are still structurally under "decentralized despotism." This entails a colonial genealogy of the "bifurcated state," which rules the rural and urban separately. ${ }^{83}$ The consequences of this bifurcation are xeno-racist protection of urban sites from the non-insured refugees.

It has long been known that large numbers of refugees live in major African cities. ${ }^{84}$ Today hundreds of thousands of refugees, both registered and unregistered, reside in cities such as Nairobi, Dar es Salaam, Addis Ababa, and Johannesburg. Loren Landau argues against parallel aid systems such as cash transfers in cities because the majority of urban displaced in Africa are "more robust and resilient as the truly vulnerable are." ${ }^{85}$ While this is largely true, others argue that those with significant vulnerabilities also reside in urban centres such as Nairobi ${ }^{86}$ or Kampala ${ }^{87}$ It would be feasible to target vulnerable populations in African cities in similar ways to Jordan, especially with the proliferation of mobile money in Africa such as Safaricom's M-Pesa. African states have pushed back on allowing refugees from neighbouring states to live in cities. However, countries hosting Syrian refugees have deemed them a worthy and bio-legitimate urban population.

To illustrate, most major refugee-hosting states in Africa have instituted large-scale cash transfer programs in refugee camps and settlements. No African countries, however, apart from Egypt, Sudan, ${ }^{88}$ and Niger ${ }^{89}$ have introduced cash for urban refugees. These are available mostly for Syrian refugees. Egypt hosts an estimated 500,000 Syrians, around 130,000 of whom are registered..$^{90}$ Egypt is the only African country that is part of Regional Refugee and Resilience Response Plan (3RP) to coordinate care for Syrian refugees. As part of 3RP, by 2016 UNHCR and WFP was providing nearly 42,000 Syrian refugees in Cairo with cash assistance. ${ }^{91}$ There is a separate small program by Caritas Egypt, which provides a small number of cash grants to "extremely vulnerable" households, and only bimonthly for six months. ${ }^{92}$ One study found that only 13 per cent of Sudanese households received this assistance. ${ }^{93}$ SsA refugees such as Sudanese, Ethiopians, Somalis, Eritreans, and others have been displaced to Egypt for decades. They constantly face xenophobic discrimination and have not been included in urban cash programs. ${ }^{94}$ By following the cash, this shows that donors and host states deem Syrian refugees worthy only to live in cities with cash assistance.

One humanitarian cash researcher says that UNHCR in Africa has "vanishingly tiny budgets." As such, urban aid programs are some of the first items to be cut in a budget. ${ }^{95}$ In 2017 the appeal for 24.2 people of concern in Africa was $\$ 2.925$ billion, but met a funding gap of 53 per cent of this amount. ${ }^{96}$ In comparison, the $3 \mathrm{RP}$ in 2017 , which funds the cash transfers for Syrian refugees in Cairo, requested $\$ 5.58$ billion for a refugee population of 5.3 million refugees. 3RP had a smaller funding gap of 63 per cent. ${ }^{97}$ This demonstrates a funding ambivalence toward ss refugees reminiscent of Eritrean repatriates in the 1990s. However, in situations with donor apathy toward ssa refugees such as Sudan and Egypt refugee operations, it opens the space for historic xeno-racist processes to be accentuated in refugee policies and interventions such as cash transfers.

Social exclusion for black Africans in Egypt and Sudan has a long history at the intersection of Arab expansion and slave trade in Africa. ${ }^{98}$ Unfortunately for the sake of brevity, this article cannot expound upon the history. However, works from Troutt Powell trace the complex racial genealogies from colonialism, which recount how African states such as Egypt and Sudan became "colonized colonizers." 99 Arabization has been a central cause of wars for decades, in Sudan in particular. ${ }^{100}$ With low funding and involvement from the international community, xeno-racist exclusion for black Africans is revealed in refugee cash transfer programming. As a result, ssa refugees must struggle unassisted or even persecuted in cities or live in camps-the only biolegitimate place for them. Cash-based interventions have acquiesced to host states' desires to keep refugees confined to the peripheries of their countries. The final section returns to the contemporary Tanzanian refugee situation where cash has been shut down even in refugee camps, which signals that refugees are no longer welcome anywhere in the country. 


\section{Cash Shutdown in Tanzania}

The Nyarugusu refugee camp was created in 1996 in response to the first war in the Democratic Republic of Congo. Until 2015 Nyarugusu was the last remaining refugee camp in Tanzania. In 2015 Burundi's President Pierre Nkurunziza stayed in power past his constitutionally mandated second term, which led to a political crisis followed by widespread government repression. Thousands fled to Tanzania and neighbouring countries, and Nyarugusu doubled in size to nearly 150,000. Two former camps, Mtendeli and Nduta, were revived to accommodate this population boom. There are around 275,000 Burundian refugees documented in Tanzania.

The most recent arrival of Burundian refugees follows cycles of displacement from the Burundian genocide in 1972 and the civil war from 1993 to 2005. In addition to Burundian refugees, Tanzania in the 1990 s received hundreds of thousands of Rwandan and Congolese refugees. This influx led to the encampment policy enacted under the 1998 Refugees Act, which is still in effect. This law stipulates that refugees may not travel more than four kilometres outside camps and cannot seek work for wages except inside the camp. ${ }^{101}$ In Tanzania, Burundians are often pejoratively referred to as criminals. ${ }^{102}$ By 2005 , there was a clamour in Tanzania for refugees to be repatriated. President Jakaya Kikwete ran for election partially on a platform to make Tanzania "refugeefree" by 2010. At the end of 2012, the remaining Burundian refugees living in Mtabila refugee camp-nearly 40,000were forced to repatriate to Burundi against their wishes. ${ }^{103}$ The shrinking space of asylum is bringing up these fears of violent return under the current president, John Magufuli. A Burundian man in Nyarugusu voiced this anxiety: "In 2012 we were forced to go back to Burundi. We lived there three years and were forced to come back to Tanzania. The same will probably happen again. What I saw, they stole things from refugees and burned houses. They cut down crops and burned the rest. Refugees could not carry all of their property. Those who were forced last, they were forced even by weapon. This could happen again."104

Tanzania began a pilot cash program in December 2016 targeting 10,000 vulnerable refugees. Each household member received 20,000 TSh (\$9) per month. The program was set to reach 80,000 recipients, with plans to expand to Mtendeli and Nduta, but it was cancelled by the government after reaching only 30,000 individuals. On 20 July Tanzanian President Magufuli met Burundi's President Nkurunziza at the border in Ngara. President Magufuli sided with President Nkurunziza and delivered a speech claiming Burundi was safe to return to, despite UN investigations reporting serious human rights abuses. President Magufuli made a thinly veiled reference to the WFP cash program: "We all know that there are people who benefit when Burundians flee their country in droves. There are organizations raking in money in the name of helping refugees. I'm aware that there are people who lured Burundians into refugee camps in Tanzania, telling them that they would be given Sh10,0oo each daily. If they have that kind of money, they should pay them once they are back home." 105 Two weeks after this speech, on August 4, WFP announced that the government had abruptly decided to shut down the cash program, and the final distribution was cancelled. The decision came so suddenly from the central government it was claimed the camp commandant under the Ministry of Home Affairs responsible for administration and security of the camp found out the same day as the refugees. ${ }^{106}$

Other sudden shutdowns have been increasing under President Magufuli. Prior to the cash shutdown, in January 2017, prima facie status was revoked for Burundians, and asylum seekers have been turned away at the borders. ${ }^{107} \mathrm{On}$ February 9, 2018, President Magufuli unexpectedly pulled out of the Comprehensive Refugee Response Framework (CRRF), citing lack of support from the international community. The CRRF is a voluntary pilot project to re-evaluate national refugee policy in consultation with UNHCR and other stakeholders in exchange for increased international financial support. This decision left UNHCR staff and Tanzanian government bureaucrats dumbfounded. ${ }^{108}$ Most recently, in mid-July 2018, Tanzanian officials in the camps made announcements reiterating that Burundian refugees must return home. Additionally, market days were limited to once a week, and draconian restrictions on businesses in camps were enacted whereby only small petty-businesses could operate. At the time of writing, Tanzanian authorities were destroying market stalls inside Nduta refugee camp. ${ }^{109}$ Camp residents increasingly rely on livelihoods to survive, as a lack of international funding has decreased rations in the camp. This shrinking space of asylum and commerce puts into question if "voluntary returns" to Burundi are actually voluntary. ${ }^{110}$

The recent Burundian influx and subsequent cancellation of cash is further evidence that where cash is allowed, refugees are allowed. Tanzania is not alone in using cash shutdowns to signal if refugees are worthy to reside on their soil. Somalis in Kenya, like Burundians in Tanzania, have been vilified and collectively punished by the state in Kenya since independence. ${ }^{111}$ In 2015 immediately following the AlShabaab attack on Garissa University College, which killed nearly 150 students, the government of Kenya shut down all Somali remittance companies, popularly known as hawalas, for two and a half months. These actions temporarily devastated Somali refugee economies in Nairobi. ${ }^{112}$ 


\section{Conclusion}

In the cases of refugee cash operations presented, one can see how donors and hosts calculate the worth of refugees. Worth is a bio-legitimacy determined by the position of a refugee population in the global geopolitical hierarchy. Xeno-racism represents moves by states to prevent unworthy refugees from entering through immigration control or containing refugee populations. These determinations of the bio-legitimacy of refugee populations is a remnant of a racial colonial system or "colonial present," manifest dictating the movements of non-insured peoples. ${ }^{113}$ Colonial lineages are not only imposed from the North, for xeno-racist "colonized colonizers" also exist in South-South relations. ${ }^{114}$

Cambodians' worth to donors derived from a population to be mined for votes to install a new regime favourable to the West. Afghans' worth was initially tied to counteracting Soviet influence, but this transitioned to moving the Afghan caseload off ongoing aid obligations. Eritreans garnered very little worth in donors' eyes, and this was reflected in inadequate funding and no cash program. The cash programs for Iraqis in Amman and Syrians in Cairo demonstrate the high strategic importance to donors due to the war on terror and military involvement in these situations. Conceptualization of insured and non-insured can also be applied to Africa. Host states in Africa contest the legitimacy of refugees outside of camps in cities. After hosting these populations for decades, Burundians have very little bio-legitimacy to host states. In all these instances, allowing or blocking cash is a way to signal refugees' worth.

\section{Notes}

1 This author is generously funded through the Leverhulme Trust Perfect Storm Scholarship.

2 Filippo Grandi, "Opening Statement at the 68th Session of the Executive Committee of the High Commissioner's Programme," October 2, 2017, https://www.unhcr.org/admin/ hcspeeches/59dif 3 b77/opening-statement-68th-sessionexecutive-committee-high-commissioners-programme .html.

3 Franziska Troger and Vicky Tennant, The Use of Cash Grants in UNHCR Voluntary Repatriation Operations: Report of a "Lessons Learned" Workshop. UnHCR Policy Development and Evaluation Service (UNHCR: Geneva, 2008).

4 Overseas Development Institute, Doing Cash Differently: How Cash Transfers Can Transform Humanitarian Aid. Report of the High Level Panel on Humanitarian Cash Transfers (London: ODI, 2015), 1-42.

5 A. Sivanandan, "Poverty Is the New Black," Race \& Class 43, no. 2 (2001): 1-5; Liz Fekete, "The Emergence of XenoRacism," Race \& Class 43, no. 2 (2001): 23-40.

6 Sivanandan, "Poverty Is the New Black," 2.

7 Overseas Development Institute, Doing Cash Differently.
8 Nick van Praag, "Can Cash Transfers Unleash the Participation Revolution?" Ground Truth Solutions, May 23, 2018, http://groundtruthsolutions.org/2018/05/23/ can-cash-transfers-unleash-the-participation-revolution/.

9 Michel Foucault, "Nietzche, Genealogy, History," in The Foucault Reader, edited by Paul Rabinow (New York: Pantheon, 1991), 81.

10 Foucault, "Nietzche, Genealogy, History," 83.

11 All interviewees have been told the purpose of the interviews and promised protection of their data, as well as their anonymity. All participants verbally consented to participate. Understanding the power imbalance between me and the refugee population in Tanzania, I underwent a School of Social and Political Science Ethics Review at the University of Edinburgh to understand and mitigate ethical issues. While some researchers offer gifts such as mobile phone vouchers or sodas, I decided to pay refugee informants only the equivalent of two to four dollars, depending on the length of interviews, to let them decide what to purchase with the gift. In an attempt to facilitate trust, all interviews with refugees were conducted with either Congolese or Burundian refugee interpreters under my employment. All interviews with Tanzanian host community members were with Tanzanian interpreters and research assistants. Notes were taken during interviews and locked away when not carried by the researcher. Shortly after the interview, the notes were then typed, coded, and analyzed using passwordprotected NVIVo software.

12 Didier Fassin, "Another Politics of Life Is Possible," Theory, Culture \& Society 26, no. 5 (2009): 44-60.

13 Paulette Goudge, The Power of Whiteness: Racism in Third World Development and Aid (London: Lawrence \& Wishart, 2003); Sarah White, "Thinking Race, Thinking Development," Third World Quarterly 23, no. 3 (2002): 407-19.

14 White, "Thinking Race," 407-19.

15 Uma Kothari, "Critiquing 'Race' and Racism in Development Discourse and Practice," Progress in Development 6, no. 1 (2006): 1-7.

16 R. Cheran, "Xeno-Racism and International Migration," Refuge 19, no. 6 (2001): 1-3.

17 Mark Duffield, "Getting Savages to Fight Barbarians: Development, Security and the Colonial Present," Conflict, Security \& Development 5, no. 2 (2005): 141-59; Mark Duffield, "Racism, Migration and Development: The Foundations of a Planetary Order," Progress in Development Studies 6, no. 1 (2006): 68-79.

18 Morgan Brigg, "Post-Development, Foucault and the Colonisation Metaphor," Third World Quarterly 23, no. 3 (2002): 421-36.

19 Didier Fassin, "The Biopolitics of Otherness: Undocumented Foreigners and Racial Discrimination in French Public Debate," Anthropology Today 17, no. 1 (2001): 3-7; Didier Fassin, "Policing Borders, Producing Boundaries: The Governmentality of Immigration in Dark Times," Annual Review of Anthropology 40 (2011): 213-26. 
20 Duffield, "Getting Savages"; Duffield, "Racism, Migration, and Development."

21 Michel Foucault, The History of Sexuality (London: Penguin, 1979), 138.

22 Foucault, History of Sexuality, 138.

23 Foucault, History of Sexuality, 139.

24 Duffield, "Getting Savages."

25 Duffield, "Racism, Migration, and Development."

26 Mahmood Mamdani, Citizen and Subject (Kampala: Fountain Publishers, 1996).

27 Duffield, "Getting Savages," 150.

28 Duffield, "Getting Savages," 149.

29 Tanganyika is the name of mainland of modern Tanzania. The name Tanzania came in 1964 when independent Tanganyika joined in a republic with People's Republic of Zanzibar and Pemba, two islands off the coast.

30 Sreeram Sundar Chaulia, "The Politics of Refugee Hosting in Tanzania: From Open Door to Unsustainability, Insecurity and Receding Receptivity," Journal of Refugee Studies 16, no. 2 (2003): 147-66.

31 Chaulia, "Politics of Refugee Hosting."

32 Deborah Fahy Bryceson, "African Peasants' Centrality and Marginality: Rural Labour Transformations," in Disappearing Peasantries: Rural Labour in Africa, Asia and Latin America, edited by Deborah Fahy Bryceson, Cristobal Kay, and Jos. Mooij, 37-63 (London: IT Publications, 2000).

33 Deborah Posel, The Making of Apartheid 1948-1961: Conflict and Compromise. Oxford Studies in African Affairs (Oxford: Clarendon, 1991).

34 Andrew Burton, African Underclass: Urbanisation, Crime and Colonial Order in Dar es Salaam (Oxford: James Currey, 2005).

35 Charlotte Lee Miller, "Who Are the 'Permanent Inhabitants' of the State? Citizenship Policies and Border Controls in Tanzania, 1920-1980" (PhD diss., University of Iowa, 2011).

36 Liisa Malkki, Purity and Exile: Historical Memory and National Identity among Hutu Refugees in Tanzania (Chicago: University of Chicago Press, 1995).

37 Chaulia, "Politics of Refugee Hosting," 156.

38 Sivanandan, "Poverty Is the New Black," 2.

39 Duffield, "Getting the Savages"; Duffield, "Racism, Migration and Development."

40 Bonaventura Rutinwa, The End of Asylum? The Changing Nature of Refugee Policies in Africa, New Issues in Refugee Research, Research Paper No. 5, Geneva, UNHCR, 1999.

41 UNHCR, Handbook for Self-Reliance (Geneva: UNHCR, 2005); Easton-Calabria and Omata, "Panacea for the Refugee Crisis?"

42 Kevin Dunbar and James Milner, The HumanitarianDevelopment Nexus: Opportunities for Canadian Leadership, RRN/Crs Policy Brief 2016.

43 Alexander T. Aleinikoff, From Dependence to Self-Reliance: Changing the Paradigm in Protracted Refugee Situations. Policy Brief (Washington, DC: Migration Policy Institute, 2015).
44 Overseas Development Institute, Doing Cash Differently.

45 Fassin, "Another Politics of Life," 52.

46 Fassin, "Another Politics of Life," 52.

47 Duffield, "Racism, Migration and Development," 76.

48 B.S. Chimni, "The Geopolitics of Refugee Studies: A View from the South," Journal of Refugee Studies 11, no. 4 (1998): $350-74$.

49 Marita Eastmond and Joakim Öjendal, "Revisiting a 'Repatriation Success': The Case of Cambodia," in The End of the Refugee Cycle? edited by Khalid Koser and Richard Black, 38-55 (New York: Berghahn Books, 1999).

50 Eastmond and Öjendal, "Revisiting a 'Repatriation Success," 43.

51 Peter Marsden, "Afghans in Pakistan: Why Rations Decline," Journal of Refugee Studies 5, no. 3/4 (1992): 29-30.

52 Marsden, "Afghans in Pakistan," 299.

53 David Turton and Peter Marsden, Taking Refugees For a Ride? The Politics of Refugee Return to Afghanistan. Issue Paper Series (Kabul: Afghanistan Research and Evaluation Unit, 2002), 15.

54 UNHCR, Repatriation under Conflict: A Review of the Encashment Programme for Afghan Refugees In Pakistan (UNHCR: Geneva, 1994), para. 47.

55 UNHCR, Repatriation under Conflict, para. 68.

56 Commissioner's Office for Refugees (COR), Statistical Report, Documentation Centre (Khartoum) 1993, cited in Gaim Kibreab, "Left in Limbo: Prospects for Repatriation of Eritrean Refugees from the Sudan and Responses of the International Donor Community," in In Search of Cool Ground: War, Flight and Homecoming in Northeastern Africa, edited by Tim Allen (London: James Currey, 1996), 58.

57 Gaim Kibreab, "When Refugees Come Home: The Relationship between Stayees and Returnees in Post-Conflict Eritrea," Journal of Contemporary African Studies 20, no. 1 (2002): 53-80.

58 Kibreab, "Left in Limbo," $56-7$.

59 Kibreab, "Left in Limbo," 58.

60 Kibreab, "Left in Limbo," 58.

61 Kibreab, "Left in Limbo," 63-4.

62 Gaim Kibreab, "Displaced Communities and the Reconstruction of Livelihoods in Eritrea (United Nations University WIDER World Institute for Development Economics Research, 2001): 1.

63 Kibreab, "Left in Limbo," 64.

64 Troger and Tennant, Use of Cash Grants.

65 Interview with UNHCR employee, Geneva, July 7, 2017.

66 UNHCR, Statistics on Displaced Iraqis around the World: Global Overview, September 2007.

67 Jeff Crisp, Jane Janz, Jose Riera, and Shahira Samy, Surviving in the City: A Review of UNHCR's Operation for Iraqi Refugees in Urban Areas of Jordan, Lebanon and Syria, UNHCR Policy Development and Evaluation Service, Geneva, 2009. 68 Interview with UNHCR employee, Geneva, July 7, 2017. 69 Interview with UNHCR employee. 
70 Interview with UNHCR employee.

71 Andrew Harper, "Iraq's Refugees: Ignored and Unwanted," International Review of the Red Cross 90, no. 869 (2008): 172.

72 Crisp et al., Surviving the City, 9.

73 Interview with UNHCR employee, Geneva, July 7, 2017.

74 Interview with UNHCR employee.

75 Crisp et al., Surviving the City, 43.

76 To compare, Tanzania сві in Nyarugusu refugee camp gave 20,000 Tanzanian shillings (about 7 euros) per person.

77 Ibid.

78 Crisp et al., Surviving the City, 9.

79 Crisp et al., Surviving the City, 3.

80 Crisp et al., Surviving the City; Jeff Crisp, "Finding Space for Protection: An Inside Account of the Evolution of UNHCR's Urban Refugee Policy," Refuge 33 no. 1 (2017): 1-58.

81 Interview with former UNHCR employee, April 5, 2017.

82 UNHCR, UNHCR Policy on Refugee Protection and Solutions in Urban Areas (Geneva: UNHCR, 2009), 19.

83 Mamdani, Citizen and Subject.

84 Brian Neldner, "The Settlement of Rural Refugees in Africa," Disasters 3, no. 4 (1979): 393-402; Gaim Kibreab, "Eritrean and Ethiopian Urban Refugees in Khartoum: What the Eye Refuses to See," African Studies Review 39 no. 3 (1996): 13178; Marc Sommers, Fear in Bongoland: Burundi Refugees in Urban Tanzania (New York: Berghahn, 2001); Elizabeth Campbell, "Urban Refugees in Nairobi: Problems of Protection, Mechanisms of Survival, and Possibilities for Integration," Journal of Refugee Studies 19, no. 3 (2006): 396-413.

85 Loren Landau, "Urban Refugees and IDps," in The Oxford Handbook of Refugee and Forced Migration Studies, edited by Elena Fiddian-Qasmiyeh, Gil Loescher, Katy Long, and Nando Sigona (Oxford: Oxford University Press, 2014), 140.

86 Clayton Boeyink, "After Garissa: Social Capital and Vulnerability among Somali Refugees in Nairobi," Refugee Review 3 (2017): 162-76.

87 Will Monteith and Shuaib Lwasa, "The Participation of Urban Displaced Populations in (In)formal Markets: Contrasting Experiences in Kampala, Uganda," Environment \& Urbanization 29 no. 2 (2017): 382-402.

88 I was unable to find official UNHCR documents for the cash program in Khartoum and did not receive a response from UNHCR. One OCHA Humanitarian Bulletin mentioned cash assistance is being provided to Syrians in Khartoum. OCHA, Humanitarian Bulletin Sudan Issue 40.

89 At the time of distribution there were a relatively small number of Malian refugees residing in Niamey, Niger. Of these, the program targeted only 625 households for only four months, rather than in an ongoing and sustained fashion. See Pantaleo Creti, Mobile Cash Transfers for Urban Refugees in Niamey, Niger (Oxford: Cash Learning Partnership, 2014).

90 3RP: Regional Refugee \& Resilience Plan 2018-2019 in Response to the Syria Crisis. Regional Strategic Overview (2018).
91 3RP: Regional Refugee \& Resilience Plan in Response to the Syria Crisis: Egypt (2017).

92 "Refugee Support Along the Mediterranean Coast," Caritas Egypt, https://caritas-egypt.org/en/project/refugees-alex/.

93 Karen Jacobsen, Maysa Ayoub, and Alice Johnson, "Sudanese Refugees in Cairo: Remittances and Livelihoods," Journal of Refugee Studies 27, no. 1 (2014): 154.

94 Jacobsen, Ayoub, and Johnson, "Sudanese Refugees in Cairo," 153.

95 Interview with a humanitarian researcher, February 2, 2018. 96 UNHCR, UNHCR Global Report 2017 (Geneva: UNHCR, 2018), 75.

97 3RP Regional Strategic Overview 2019/2020 (2018): 4.

98 Leben Nelson Moro, "Interethnic Relations in Exile: The Politics of Ethnicity among Sudanese Refugees in Uganda and Egypt," Journal of Refugee Studies 17, no. 4 (2004): 420-36.

99 Eve Troutt Powell, A Different Shade of Colonialism Egypt, Great Britain, and the Mastery of the Sudan (Berkeley: University of California Press, 2003).

100 Douglas H. Johnson, The Root Causes of Sudan's Civil Wars. African Issues. (Oxford: Currey, 2003); Heather J. Sharkey, "Arab Identity and Ideology in Sudan: The Politics of Language, Ethnicity, and Race," African Affairs 107, no. 426 (2008): 21-43.

101 Khoti Kamanga, "The (Tanzania) Refugees Act of 1998: Some Legal and Policy Implications," Journal of Refugee Studies 18, no. 1 (2005): 100-16.

102 Diana Felix da Costa, "You May Think He Is Not a Human Being: Refugee and Host Community Relations in and around Nduta and Mtendeli Refugee Camps, Western Tanzania," Danish Refugee Council, 2017.

103 Lucy Hovil and Theodore Mbazumutima, "Tanzania's Mtabila Camp Finally Closed," Pambazuka News, 2012, https://www.pambazuka.org/governance/ tanzania's-mtabila-camp-finally-closed.

104 Interview with Burundian man in Nyarugusu camp, August 22, 2017.

105 "Magufuli: No Citizenship for Burundi Refugees," Citizen, July 21, 2017, http://www.thecitizen .co.tz/News/Magufuli--No-citizenship-for-Burundirefugees/1840340-4025670-format-xhtml-6dymcc/index .html.

106 Interview with refugee present at meeting between UNHCR, WFP, and Camp Commandant, Nyarugusu camp, August 12, 2017.

107 UNHCR, Burundi Regional Refugee Response Plan January-December 2018, Regional Refugee Coordination Office (Nairobi: UNHCR, 2018), 55.

108 Interview with UNHCR employee, Dar es Salaam, February 19, 2018.

109 Interview with Burundian man in Nyarugusu camp via Skype, March 31, 2019.

110 Thijs Van Laer, "'There Is Pressure on Us," Burundian Refugees in Tanzania Pushed to Return," 
African Arguments, accessed September 14, 2018, https:// africanarguments.org/2018/08/21/pressure-burundirefugees-tanzania-pushed-return/.

111 Emma Lochery, "Rendering Difference Visible: The Kenyan State and Its Somali Citizens," African Affairs 111, no. 445 (2012): 615-39; Hannah Alice Whittaker, "The Socioeconomic Dynamics of the Shifta Conflict in Kenya, C. 1963-8," Journal of African History 53, no. 3 (2013) : 391-408; David Anderson, "Remembering Wagalla: State Violence in Northern Kenya, 1962-1991," Journal of Eastern African Studies 8, no. 4 (2014): 1-19.

112 Boeyink, "After Garissa."
113 Duffield, "Getting the Savages."

114 Troutt Powell, Different Shade of Colonialism.

Clayton Boeyink is a PhD candidate in international development at the University of Edinburgh and is a member of the Centre for African Studies. His research focuses on the politics and practices of refugee self-reliance in East Africa generally, and cash transfers and illicit labour systems and markets in and out of camps specifically. He can be reached at clayton. boeyink@ed.ac.uk. 